combined with the instillation of highly potent antibiotic solution immediately prior to withdrawal of the catheter, the incidence of significant bacteriuria is very significantly diminished. In their experience this technique may be used for many weeks without bacteriuria occurring. An additional advantage of intermittent catheterisation is that it markedly lowers the frequency of prostatitis and urethritis which are so commonly associated with the use of an indwelling catheter. Provided over-distension is avoided, the cyclical filling of the bladder which occurs with intermittent catheterisation stimulates stretch receptors in the bladder wall and promotes an earlier return of reflex detrusor activity in cases which have an intact spinal reflex arc for micturition.' A very good confirmation of the reviewer's teaching.

This is an excellent monograph written very clearly and very well illustrated, which can be highly recommended to everyone concerned with the treatment of spinal paraplegics and tetraplegics.

YOU CAN DO IT FROM A WHEELCHAIR. By ARLENe E. Gilbert. Publishers: Arlington House Publishers, New Rochelle, N.Y., I974. 142 pages.

The author who is disabled from multiple sclerosis since 1965, has four children to look after. She significantly writes 'When I got out of hospital (I spent a year in one) there was no literature to guide me, I had to do everything by trial and error. Especially when trying to keep house, I hadn't the slightest notion how to begin.' Now she writes in this cheerful and optimistic book how she managed to lead a nearly normal life. The contents of the book give basic wheelchair information, household arrangements, aids, meal preparation, general housekeeping, floor care, laundry, child care, personal grooming and other activities. This book is illustrated with instructive photographs and the whole book is indeed an inspiration for all wheelchair users.

SIR Ludwig GutTManN

\title{
ABSTRACTS \\ SURGICAL TREATMENT OF MYELOPATHY WITH CERVICAL SPONDYLOSIS
}

\author{
By Douglas G. Phillips (Bristol)
}

THE author reports about the results of treatment over a period of IO years on I02 cases of cervical spondylosis complicated with myelopathy. A follow-up in all cases to 2 years after the end of that period was carried out. Best results ( 73 per cent. sustained improvement) were obtained in 65 cases treated by an anterior approach. Of 48 patients showing sustained improvement, 38 returned to and remained at work. The results of operation from an anterior approach with careful and thorough removing of projecting osteophytes and disc substance are markedly superior to those of laminectomy or conservative treatment. Post-operative hoarseness may result from damage to the recurrent laryngeal nerve. Horner's syndrome was seen, attributable to damage to the sympathetic nerve. The jugular vein may be damaged if small tributaries are torn close to their entry into the vein. Moreover, damage to the upper part of the brachial plexus was also seen as a result of slipping of an inadequately held drill before it entered the bone.

It would be of interest to follow up these cases for a longer period than 2 years.

\section{REFERENCE}

Fourn. of Neurology, Neurosurgery \& Psychiat. (1973), 36, 879-884. I2/I-E 


\title{
PARACHUTING INJURIES
}

\author{
By Colonel N. G. KIRBY (British Army of the Rhine)
}

THE author gives an analysis of parachuting injuries over a 5-year period on 520 injuries severe enough to warrant admission to hospital. Amongst the various injuries were 42 to the vertebral column, two involving cervical, three TI-II and 32 the thoraco-lumbar spine, amongst the latter 10 affecting $T_{12}$ and LI. Five were unspecified. The majority of vertebral injuries were caused by hard landings and back flops. There was only one case of spinal cord involvement and several developed 'sciatica'. One patient died from pulmonary embolus 24 days after injury, another from a fracture of the cervical spine.

\section{REFERENCE}

Proc. Roy. Soc. Med. (1974), 67, 17.

\section{EVALUATION OF RHIZOTOMY. REVIEW OF I2 YEARS EXPERIENCE}

By B. M. ONOFiro and H. K. Camap (Rochester)

THE authors report about 286 rhizotomies which were carried out at the Mayo Clinic. One hundred and twelve patients had been of unknown aetiology. Beneficial effects were found between 25 and 50 per cent. Rhizotomies which were carried out for patients with cancer showed only in five out of I8 cases any effect. In four of five rhizotomies carried out for herpes zoster there was a recurrence within 5 years. In 45 patients with S I root pain only six patients showed satisfactory results and in L5 root pain only three of I3 patients benefited. The authors conclude that rhizotomy only shows moderate to bad results.

\section{REFERENCE}

Zentralblatt für Neurochirurgie (1973), Band 34, Heft I, 59.

\section{MORPHOLOGIE, PATHOPHYSIOLOGIE UND KLINIK DER 'INTERSPINALEN MENINGOCELE'}

By Hammer B. and H. STEINHÄUSL (Linz)

THE symptomatology of the intraspinal meningocele with enlargement of the spinal canal over several segments and with protrusion of the meningeal sac is described and the $\mathrm{X}$-ray findings reported. The pathogenesis of this congenital abnormality is discussed in relationship to neuro-fibromatosis. In view of the possible operative treatment, the disturbances of the cerebrospinal fluid should be examined with the help of isotopes and the absorption of the CSF should also be examined. Intraspinal injections of Conray 60 showed significant delay in the absorption of the dye.

\section{REFERENCE}

Zentralblatt für Neurochirurgie (1973), Band 34, Heft I, 58. 